\title{
Students' mathematical critical thinking ability in problem-based learning viewed based on learning style
}

\author{
Bambang Eko Susilo \\ Mathematics Department, Universitas Negeri Semarang, Central Java, Indonesia \\ *Correspondence: bambang.mat@mail.unnes.ac.id \\ (C) The Author 2022
}

\begin{abstract}
The development of mathematical critical thinking ability and individual uniqueness in the learning of prospective teacher students needs attention so that they have sufficient provisions in their future work. This study aims to analyze the differences in prospective teacher students' mathematical critical thinking ability in their achievement and improvement from two different learning models and their learning styles. Problem-based learning was used in the experimental group, while the control group used conventional learning. This study used a quasiexperimental quantitative method with the pretest-posttest non-equivalent group design. Data were collected using: mathematical critical thinking ability test and a learning style questionnaire. Data were taken from 56 students of the Mathematics Education Study Program, Universitas Negeri Semarang. Data analysis was performed using independent samples t-test, Mann-Whitney U test, and normalized gain. The results showed that in the achievement and improvement of mathematical critical thinking ability, students who obtained Problem-based learning overall and viewed from a kinesthetic learning style were better than conventional learning. Meanwhile, in terms of auditory and kinesthetic learning styles, the mathematical critical thinking ability of students who obtained descriptive problem-based learning was better. However, in statistical testing, the two groups were not significantly different. Based on these results, Problem-based learning is considered adequate for developing mathematical critical thinking ability, especially for kinesthetic learning styles.
\end{abstract}

Keywords: learning style; mathematical critical thinking ability; problem-based learning

Received: 21 November 2021 | Revised: 3 December 2021

Accepted: 23 December 2021 | Published: 6 January 2022 


\section{Introduction}

Critical thinking ability is one of the primary skills needed in the 21 st century, including problem-solving, creativity, innovation, and communication and collaboration. Critical thinking ability is essential for higher-order thinking skills (Trilling \& Fadel, 2009; FitzPatrick \& Schulz, 2015). Critical thinking abilities, which are higher-order thinking skills, are needed to solve problems in mathematics and complex problems in multinational and multicultural relations. Critical thinking in the process requires thinking activities such as analyzing, evaluating and concluding (Paul \& Elder, 2013; Asyari et al., 2016; Widiawati et al., 2018). Therefore, critical thinking is one of the primary keys needed to develop other skills needed in various jobs in the future. Complex problem solving, critical thinking, creativity, community management, coordination, emotional intelligence, making judgments and decisions, serviceoriented, negotiation, and flexible thinking (Gleason, 2018).

The spearhead to develop students' critical thinking ability are teachers, including mathematics teachers. Based on this reason, developing the ability of prospective teacher students to think critically should be the focus of higher education, including universities that produce teacher candidates in the Mathematics Education Undergraduate Study Program. This development effort is carried out to provide academic training for prospective teacher students as the spearhead of education, which will carry out critical thinking development for students in primary and secondary education. Among the intellectual training is that in solving problems, students are not enough just to understand the material, but also need to analyze or clarify the data provided (clarification), provide an evaluation or assessment by giving examples or reasons (assessment), make conclusions or inference (inference), and making strategies of problem-solving (strategies) (Perkins \& Murphy, 2006; Vong \& Kaewurai, 2017; Susilo et al., 2019).

Critical thinking abilities have been attempted to be developed with various models, approaches, learning strategies, one of which is Problem-based learning (Şendağ \& Ferhan Odabaşi, 2009; Alrahlah, 2016; Gholami et al., 2016). Problem-based learning is a learning model with student-centered characteristics that provide students with real-world problems to facilitate learning about critical thinking and problem-solving skills and gain knowledge and essential concepts from lecture material (Ali, 2019). The stages in the problem-based learning process include the following: (1) the teacher gives problems to students, (2) the teacher asks students to discuss in small groups, (3) the teacher asks students to conduct studies related to problems that must be solved independently, (4) then the teacher asks students to return to their original groups to exchange information, study with peers, and work together to solve problems, (5) the teacher asks students to present the solutions they have found, and (6) the teacher helps students to evaluate all learning activities that have been carried out. have been done (Barrett et al., 2005; Gorghiu et al., 2015; Alrahlah, 2016; Darhim et al., 2020).

Zamzam's research (2016) reveals that implementing problem-based Learning can develop students' critical thinking ability. Several studies, including Hussain and Anwar (2017), Mulyanto et al. (2018), Saputra et al. (2019), and Nadeak and Naibaho (2020), also show the effectiveness of Problem-based Learning in developing critical thinking ability. 
Several research results show that the critical thinking ability of prospective teacher students in Calculus lectures is not satisfactory. The results of research conducted by Zetriuslita et al. (2016) explained that students' critical thinking ability in solving integral calculus description problems, in identifying and giving reasons indicators is $7.69 \%$, in generalizing $82.05 \%$, and in analyzing and evaluate by $15.38 \%$. Likewise, the results of research conducted by Nursyahidah and Albab (2018), which identified students' mathematical critical thinking ability in integral calculus; they found that there were students who were able to formulate problems correctly but incompletely; had not been able to determine the facts in the problem entirely and correctly; have not been able to use the correct evidence, have not been able to conclude according to facts; have not been able to act by providing further explanations; and have not been able to combine tendencies and abilities in making decisions. Similar results were obtained from the results of the calculus exam, which showed that students' mathematical critical thinking ability on the indicators (1) in data analysis, students who answered with problem analysis were $38.71 \%$, (2) in assessing or evaluating the truth of arguments, students who answered by evaluating the truth of the argument as much as $12.90 \%$, (3) in concluding and providing logical arguments from the results of the analysis, students who answered by concluding as much as $74.19 \%$, and (4) in formulating problem-solving strategies, students who answered by showed ideas and strategies as much as $48.39 \%$.

Based on these data, it can be concluded that some of the prospective teacher students have mathematical critical thinking ability in the poor category in Calculus lectures. It is possible to impact student learning outcomes and mathematical critical thinking ability so that in the long term, it will also have an impact on the development of students' mathematical critical thinking ability in elementary and secondary schools.

The results of developing students' critical thinking ability as above can be caused because, in the learning process, students experience difficulties, among others, because they are not following their learning styles in receiving, organizing, and processing new information in learning activities (Laksana, 2019). A person's learning style can be classified into three types of learning styles, namely visual, auditory or kinesthetic learning styles, but it does not rule out combinations (DePorter \& Hernacki, 2010). The uniqueness of student learning styles that are not facilitated in a learning strategy causes students to have difficulty absorbing, organizing, and processing the information they have just received (Susilo, 2011). With this difference in student learning styles, it is possible to impact learning achievement, not least in the development of critical thinking ability in their achievement and improvement.

This study aims to analyze the differences in prospective teacher students' mathematical critical thinking abilities in their achievement and improvement in terms of their learning styles. Mathematical critical thinking ability in the research question is how to achieve and improve it in terms of learning styles and overall students in problem-based learning.

\section{Methods}

This quasi-experimental study used the pretest-posttest non-equivalent group research design as presented in Figure 1. The quasi-experimental design was chosen because it could not fully 
control the influence of external variables in the study. The non-equivalent design was chosen because the experimental and control groups had not been equated with randomization. $\mathrm{O} 1$ and $\mathrm{O} 2$ are pretest and posttest in the experimental group, while $\mathrm{O} 3$ and $\mathrm{O} 4$ are pretest and posttest in the control group. The population in this study were all students participating in the Integral Calculus course at Universitas Negeri Semarang in the even semester 2018/2019 from the Mathematics Education Undergraduate Study Program.

$\begin{array}{llrr}\text { Experimental } & \mathrm{O}_{1} & \chi & \mathrm{O}_{2} \\ & -\ldots & - & - \\ \text { Control } & \mathrm{O}_{3} & & \mathrm{O}_{4}\end{array}$

Figure 1. The pretest-posttest non-equivalent group design, adapted from Cohen et al. (2007) Sampling in this study used cluster random sampling technique from six classes or study groups without superior-inferior groups on their academic abilities because students were free to choose their groups. The sample was selected from the fifth group (experimental group) with 28 students and the second group (control group) with 28 students. The experimental group learning model used Problem-based Learning (PBL), while the control group used conventional learning (CL). The research instruments used include a mathematical critical thinking ability test and a learning style questionnaire. The critical thinking ability test is in the form of an essay and consists of four questions. The four items represent four indicators of critical thinking ability, which were adapted from Perkins and Murphy (2006). The indicators of the mathematical critical thinking ability test questions used are (a) analyzing a statement or question, (b) concluding and providing logical arguments for the results of the analysis, (c) assessing or evaluating the truth of the arguments, and (d) developing problem-solving strategies. Students are classified based on visual, auditory, and kinesthetic learning styles. In this study, the combination was not used. The two research instruments were then tested for validity and reliability. The critical thinking ability test has been tested, the results obtained are four valid items, and the Cronbach's Alpha reliability index is 0.702. The learning style questionnaire has been tested and obtained as many as 24 valid statement items, and the Cronbach's Alpha reliability index is 0.827 .

The research process begins with classifying students based on their learning styles. The classification process was carried out by distributing learning style questionnaires to both groups of students, and only students in the visual, auditory, and kinesthetic learning styles categories were studied. The next step is to test the normality, homogeneity, and differences in the average students' initial abilities from the exam scores of the two groups. Giving a pretest of mathematical critical thinking ability is carried out at the beginning of the lecture. After seven lecture meetings, students were given a posttest of mathematical critical thinking ability. The data on the mathematical critical thinking ability test scores from the pretest and posttest based on learning styles and overall were then analyzed statistically by inference with independent samples t-test, Mann-Whitney U test, and normalized gain. The normalized gain score category (N-gain) for increasing students' mathematical critical thinking ability is classified according to Table 1 (Hake, 1998). 
Table 1. Normalized gain score category

\begin{tabular}{cc}
\hline Ngain Score Interval & Normalized Gain Score Category \\
\hline $0.7 \leq \mathrm{x} \leq 1.0$ & High \\
$0.3 \leq \mathrm{x}<0.7$ & Moderate \\
$0.0 \leq \mathrm{x}<0.3$ & Low \\
\hline
\end{tabular}

\section{Results}

Classification of students based on the results of the learning style questionnaire as presented in Table 2. This study selected only students in the visual, auditory, and kinesthetic learning styles categories as research samples. Based on Table 2, in the Problem-based learning (PBL) group, there were nine visual students, 12 auditory students, and seven kinesthetic students. Meanwhile, in the Conventional Learning (CL) group, there were nine visual students, eight auditory students, and 11 kinesthetic students.

Table 2. Classification of student learning styles

\begin{tabular}{cccc}
\hline \multirow{2}{*}{ Learning Style } & \multicolumn{2}{c}{ Learning Model } & \multirow{2}{*}{ Total } \\
& PBL & CL & 18 \\
Visual & 9 & 9 & 18 \\
Auditory & 12 & 8 & 20 \\
Kinesthetic & 7 & 11 & 18 \\
Total & $\mathbf{2 8}$ & $\mathbf{2 8}$ & $\mathbf{5 6}$ \\
\hline
\end{tabular}

The data from the pretest and posttest results of mathematical critical thinking ability were processed and analyzed as a whole and in terms of learning styles to obtain research conclusions. Based on the data from the pretest results of mathematical critical thinking ability, the mean and standard deviation are obtained as presented in Table 3.

Table 3. Mathematical critical thinking ability pretest results

\begin{tabular}{lcccccc}
\hline \multirow{2}{*}{ Learning Style } & \multicolumn{3}{c}{ Experimental Group } & \multicolumn{3}{c}{ Control Group } \\
\cline { 2 - 7 } & $\mathbf{N}$ & Mean & Std. Deviation & $\mathbf{N}$ & Mean & Std. Deviation \\
\hline Visual & 9 & 12.11 & 5.58 & 9 & 11.33 & 6.50 \\
Auditory & 12 & 13.58 & 6.02 & 8 & 13.75 & 6.76 \\
Kinesthetic & 7 & 11.86 & 1.95 & 11 & 10.18 & 5.00 \\
Overall & 28 & 12.68 & 5.05 & 28 & 11.57 & 5.98 \\
\hline
\end{tabular}

Note: The Ideal Maximum Score of mathematical critical thinking ability is 40

Based on Table 3, the mean pretest score of mathematical critical thinking ability for the experimental group in terms of overall visual and kinesthetic learning styles was higher than the control group. In contrast, the experimental group's mean pretest score of mathematical critical thinking ability in terms of auditory learning style is lower than the control group. Based on the assumption test with $\alpha=0.05$, only data for the overall and normal and homogeneous auditory learning styles were obtained, while the data for the visual learning style was not normal and the data for the kinesthetic learning style was not homogeneous. Furthermore, the independent samples t-test was carried out for the overall and auditory learning styles to find out the significant difference in mean scores. The Mann-Whitney U test was performed for the visual and kinesthetic learning styles. Summary of test results with $\alpha=0.05$ data calculation is presented in Table 4. 
Table 4. Independent pretest results samples t-test and Mann-Whitney U

\begin{tabular}{ccccc}
\hline Learning Style & Statistic Test & Statistical Value & Sig. & Ho \\
\hline Visual & Mann-Whitney U & 38.500 & 0.859 & Accepted \\
Auditory & t-Test & -0.058 & 0.955 & Accepted \\
Kinesthetic & Mann-Whitney U & 36.500 & 0.856 & Accepted \\
Overall & t-Test & 0.748 & 0.458 & Accepted \\
\hline
\end{tabular}

Based on Table 4, the results of testing the average difference in the pretest data on mathematical critical thinking ability in terms of overall and visual, auditory, and kinesthetic learning styles obtained sig. $>\alpha$ so that $\mathrm{H} 0$ is accepted. The conclusion obtained is no significant difference in the mean pretest score of mathematical critical thinking ability in the two groups in terms of overall and visual, auditory, and kinesthetic learning styles. Next is the posttest score data or the achievement of mathematical critical thinking ability. The mean and standard deviation are obtained as presented in Table 5.

Table 5. Mathematical critical thinking ability posttest results

\begin{tabular}{lcccccc}
\hline \multirow{2}{*}{ Learning Style } & \multicolumn{3}{c}{ Experimental Group } & \multicolumn{3}{c}{ Control Group } \\
& N & Mean & Std. Deviation & N & Mean & Std. Deviation \\
\hline Visual & 9 & 27.56 & 10.54 & 9 & 21.44 & 5.22 \\
Auditory & 12 & 27.42 & 9.66 & 8 & 24.88 & 5.79 \\
Kinesthetic & 7 & 27.43 & 5.94 & 11 & 18.36 & 6.39 \\
Overall & 28 & 27.46 & 8.88 & 28 & 21.21 & 6.26 \\
\hline
\end{tabular}

Note: The Ideal Maximum Score of mathematical critical thinking ability is 40

Based on Table 5, the mean posttest score or the achievement of mathematical critical thinking ability for the experimental group in terms of overall, visual, and kinesthetic learning styles were higher than the control group. Based on the assumption test with $\alpha=0.05$, the data obtained in terms of overall, auditory, and kinesthetic learning styles are normal and homogeneous. In contrast, the data for visual learning styles are not homogeneous. Furthermore, to find out the significant difference in the mean scores, the independent samples t-test was conducted for the overall, auditory and kinesthetic learning styles. In contrast, the Mann-Whitney U test was performed for the visual learning styles. Summary of test results with $\alpha=0.05$ data calculations is presented in Table 6 .

Table 6. Independent posttest results samples t-Test and Mann-Whitney U

\begin{tabular}{ccccc}
\hline Learning Style & Statistic Test & Statistical Value & Sig. & $\mathbf{H}_{\mathbf{0}}$ \\
\hline Visual & Mann-Whitney U & 27.000 & 0.233 & Accepted \\
Auditory & t-Test & 0.665 & 0.514 & Accepted \\
Kinesthetic & t-Test & 3.011 & 0.008 & Rejected \\
Overall & t-Test & 3.045 & 0.004 & Rejected \\
\hline
\end{tabular}

Based on Table 6 , the results of testing the average difference in posttest data or the achievement of mathematical critical thinking ability in terms of visual and auditory learning styles obtained the value of sig. $>\alpha$ so that $\mathrm{HO}$ is accepted, while in terms of overall and kinesthetic learning styles, sig. $<\alpha$ so that $\mathrm{H} 0$ is rejected. The conclusion obtained is that there is no significant difference in the mean posttest score or the achievement of mathematical 
critical thinking ability in the two groups in terms of visual and auditory learning styles. In contrast, there are significant differences in terms of overall and kinesthetic learning styles.

Next is the results of the normalized gain calculation from the data scores from the pretest and posttest results of mathematical critical thinking ability in both groups in terms of overall and learning styles, the data mean $(\bar{x})$, standard deviation (SD), and normalized gain (NG) obtained are as presented in Table 7.

Table 7. Results of normalized gain calculation of mathematical critical thinking ability

\begin{tabular}{|c|c|c|c|c|c|c|c|c|c|c|}
\hline \multirow{2}{*}{ Learning Style } & \multicolumn{5}{|c|}{ Experimental Group } & \multicolumn{5}{|c|}{ Control Group } \\
\hline & n & Stat & Pretest & Posttest & NG & $\mathbf{n}$ & Stat & Pretest & Posttest & NG \\
\hline \multirow{2}{*}{ Visual } & 0 & $\overline{\bar{x}}$ & 12.11 & & 0.567 & & $\bar{x}$ & 11.33 & 21.44 & 0.334 \\
\hline & y & $\mathrm{SD}$ & 5.58 & 10.54 & 0.355 & & SD & 6.50 & 5.22 & 0.185 \\
\hline \multirow{2}{*}{ Auditory } & & $\bar{x}$ & 14.58 & 27.42 & 0.526 & \multirow{2}{*}{8} & $\bar{x}$ & 13.38 & 24 & 0.435 \\
\hline & 12 & $\mathrm{SD}$ & 5.38 & 9.66 & 0.340 & & SD & 6.43 & 9 & 0.142 \\
\hline \multirow{2}{*}{ Kinesthetic } & & $\bar{x}$ & 11.86 & 27.43 & 0.556 & \multirow{2}{*}{11} & $\bar{x}$ & 10.64 & 18.36 & 0.279 \\
\hline & 7 & $\mathrm{SD}$ & 1.95 & & 0.192 & & SD & 5.75 & 6.39 & 0.170 \\
\hline \multirow{2}{*}{ Overall } & & $\bar{x}$ & 13.11 & 27.46 & 0.546 & \multirow{2}{*}{28} & $\bar{x}$ & 11.64 & 21.21 & 0.341 \\
\hline & 28 & $\mathrm{SD}$ & 4.86 & 8.88 & 0.305 & & SD & 6.07 & 6.26 & 0.174 \\
\hline
\end{tabular}

Note: (1) The Ideal Maximum Score of mathematical critical thinking ability is 40; (2) $\mathrm{NG}=$ Normalized Gain.

Based on Table 7, according to the normalized gain score obtained, the average increase in mathematical critical thinking ability of students who received PBL learning as a whole and in terms of learning styles according to the Hake's category (1998) in moderate qualification. Likewise, the average increase in mathematical critical thinking ability of students who obtained overall CL and in terms of visual and auditory learning styles according to Hake's category (1998) in moderate qualification. Meanwhile, the average increase in mathematical critical thinking ability of students who obtained CL in terms of kinesthetic learning styles according to Hake's category (1998) was included in low qualifications.

Based on Table 7. the normalized gain score of mathematical critical thinking ability for the experimental group in terms of overall and visual, auditory, and kinesthetic learning styles was higher than the control group. The assumption test with $\alpha=0.05$ obtained normalized gain data in normal and homogeneous kinesthetic learning styles. In contrast, the data in terms of overall abnormality, in terms of visual and auditory learning styles, are not homogeneous. Furthermore, the independent samples t-test was carried out for kinesthetic learning styles to find out the significant difference in mean scores. The Mann-Whitney $U$ test was performed for the overall visual and auditory learning styles. The summary of the test results with $\alpha=0.05$ calculation data is presented in Table 8 .

Table 8. Test results of independent samples t-test and Mann-Whitney U from N-gain

\begin{tabular}{ccccc}
\hline Learning Style & Statistic Test & Statistical Value & Sig. & Ho \\
\hline Visual & Mann-Whitney U & 25.000 & 0.171 & Accepted \\
Auditory & Mann-Whitney U & 46.000 & 0.877 & Accepted \\
Kinesthetic & t-Test & 3.213 & 0.005 & Rejected \\
Overall & Mann-Whitney U & 244.500 & 0.016 & Rejected \\
\hline
\end{tabular}


Based on Table 8, the results of testing the average difference of normalized gain data on mathematical critical thinking ability in terms of visual and auditory learning styles obtained sig. $>\alpha$ so that $\mathrm{HO}$ is accepted, while in terms of overall and kinesthetic learning styles, sig. $<$ $\alpha$ so that $\mathrm{H} 0$ is rejected. The conclusion obtained is no significant difference in normalized gain scores or an increase in mathematical critical thinking ability in the two groups in terms of visual and auditory learning styles. In contrast, there are significant differences in terms of overall and kinesthetic learning styles.

\section{Discussion}

Based on the research results related to the achievement of mathematical critical thinking ability, it was concluded that overall there were significant differences in the two groups. In this case, the mathematical critical thinking ability of students who received PBL learning was higher than students who received CL. These results can be seen as the data in Table 5 and Table 6, which show that there is a significant difference in the average achievement of mathematical critical thinking ability through statistical tests. So it can be concluded that the overall achievement of mathematical critical thinking ability of students who received PBL was higher than the achievement of mathematical critical thinking ability of students who received CL. The difference in the average achievement of students' mathematical critical thinking ability overall illustrates that the contribution of PBL is better than CL in developing students' mathematical critical thinking ability. The results of this study are in line with previous research, including research conducted by Zamzam (2016), Hussain and Anwar (2017), Mulyanto et al. (2018), Sianturi et al. (2018), Saputra et al. (2019), and Nadeak and Naibaho, (2020) which showed that the mathematical critical thinking ability of students who received PBL was higher than students who received CL.

Based on the results of statistical tests as in Table 5 and Table 6 , the significant difference in the average achievement of mathematical critical thinking ability between students who received PBL and students who received CL occurred in overall students and terms of kinesthetic learning styles only. In terms of visual and auditory learning styles, although the average score of the achievement of mathematical critical thinking ability of students who received PBL was higher than the average score of achievement of mathematical critical thinking ability of students who received CL, the results of statistical tests stated that they were not significantly different.

The average achievement of mathematical critical thinking ability of visual, auditory, and kinesthetic learning style students who received PBL was all good. The average achievement of mathematical critical thinking ability of visual and kinesthetic learning style students who received CL was in the less category, while the auditory learning style students were in a good category. Overall, the average mathematical critical thinking ability of students who received PBL was good, while students who received CL were poor.

Based on Table 6, descriptively, the average score of the achievement of mathematical critical thinking ability of students who obtained PBL was higher than the average score of the achievement of mathematical critical thinking ability of students who obtained CL both overall 
and in terms of learning styles (visual, auditory, and kinesthetic). It shows that in terms of learning styles (visual, auditory, and kinesthetic), PBL has a positive impact on the achievement of students' mathematical critical thinking ability, but statistically only on kinesthetic learning styles with significant differences. PBL learning steps provide varied learning facilities to students regarding learning styles. However, there is a possibility that the proportion of activities to practice working on questions is more dominant than visualizing problems and also asking questions or receiving explanations from lecturers. In PBL, students are more active in discussing and practicing questions. Factors of practice questions that contribute to the achievement of mathematical critical thinking ability of students with kinesthetic learning styles.

Theoretically, the achievement of mathematical critical thinking ability needs to be studied in the long term, as the results of Masek and Yamin's research (2011) on the impact of Problem-based Learning on critical thinking ability. The short-term empirical evidence on the findings in this study is relevant to the results of Karim (2015) and Hananto et al. (2018), which shows that the critical thinking ability of students with kinesthetic learning styles is better than the critical thinking ability of students with visual and auditory learning styles.

Based on Table 7, descriptively the average score of achievement and the average increase in mathematical critical thinking ability of students with visual learning styles who obtain PBL is higher than the average score of achievement and the average increase in mathematical critical thinking ability of students who have auditory and kinesthetic learning styles. The results of this study are in line with previous research conducted by Rosmaiyadi (2017), which also showed that students' mathematical critical thinking ability with visual learning styles was higher than students with auditory and kinesthetic learning styles.

Based on Table 7, it can be shown that in addition to students who obtained CL with kinesthetic learning styles, the overall increase in students' mathematical critical thinking ability from both learning models in terms of learning styles and overall according to Hake's qualifications (1998) the increase was in the moderate category. Meanwhile, the increase in mathematical critical thinking ability of students who obtained CL with kinesthetic learning styles was still in the low category. The statistical tests showed that the average increase in students' mathematical critical thinking ability who received PBL was significantly different from the average increase in mathematical critical thinking abilities of students who obtained CL in terms of kinesthetic learning styles and overall. It is different from statistical tests on visual and auditory learning styles, which are not significantly different. The results of this study are in line with previous research, including research conducted by Husnidar et al. (2014), Zamzam (2016), and Aziz et al. (2016), which showed that the increase in mathematical critical thinking ability of students who received PBL was higher than students who received CL.

As summarized in Table 8, it can be shown that the increase in mathematical critical thinking ability of students who received PBL in terms of kinesthetic learning styles and overall was significantly different compared to those who received CL. Similarly, the test results in Table 8. show that the increase in mathematical critical thinking ability of students who received PBL and CL in terms of visual and auditory learning styles did not differ significantly. The findings in this study are relevant to the research results of Karim (2015) and Hananto et 
al. (2018), which show that students' critical thinking abilities with kinesthetic learning styles are better than students' critical thinking ability with visual and auditory learning styles. Thus, it can be concluded that the increase in mathematical critical thinking ability of students who obtained PBL in terms of kinesthetic learning styles and overall was higher or better than those who obtained CL.

The effectiveness of PBL on students as a whole and in terms of learning styles is because there are many activity facilities provided to students to be more active to solve problems, learning activities for individuals and in small groups. Some of the learning activities facilitated in PBL include activities in discussing, exchanging knowledge, learning together, working together to solve problems, and presenting the solutions found (Barrett et al., 2005; Gorghiu et al., 2015; Alrahlah, 2016). These various learning activities support indicators of students' critical thinking ability, among others, to analyze, evaluate, conclude, and formulate strategies to solve problems (Dwyer et al., 2014; Schoenberger-Orgad \& Spiller, 2014; Samejima et al., 2015; Fajrianthi et al., 2016; Susilo et al., 2018). The thinking process of these students has a significant impact on developing students' critical thinking ability (Şendağ \& Ferhan Odabaşi, 2009; Gholami et al., 2016). So that it is obtained that the increase in mathematical critical thinking ability of students who receive PBL is higher than students who receive CL. With these results, it can be said that PBL has a better effect than CL in improving students' mathematical critical thinking ability.

Based on some of the results of this study, on the achievement and improvement of the mathematical critical thinking ability of the prospective teacher students above, similarity and consistency of results were found. These results descriptively on students as a whole and in terms of learning styles (visual, auditory, and kinesthetic). The achievement and improvement of mathematical critical thinking ability of students who receive PBL are higher than students who receive CL. However, through statistical tests only students as a whole and in terms of kinesthetic learning styles, the achievement and improvement of mathematical critical thinking ability of students who received PBL were higher than those who received CL. At the same time, the results of statistical tests on visual and auditory learning styles were not significantly different, both in the achievement and improvement of students' mathematical critical thinking ability.

In particular, the prospective teacher students with a kinesthetic learning style get a proportion of the benefits of the facility for practicing questions that are more dominant than other activities such as visualizing problems and asking questions or receiving explanations from lecturers. It is evidence of the effectiveness of PBL on the critical thinking ability of prospective teacher students who have kinesthetic learning styles where the proportion of practice questions is beneficial for students. Of course, PBL does not ignore the facilities for learning activities for prospective teacher students with other learning styles, so it is hoped that in the long term it will have an impact on the development of students' critical thinking ability in elementary and secondary schools. The results of this study are empirical evidence in the short term. In the long term, different results can occur in achieving and improving mathematical critical thinking ability in terms of other learning styles. The results of research from Masek \& Yamin (2011) show that Problem-based Learning requires a long term to impact 
critical thinking ability significantly. Furthermore, the research results from Fajari et al. (2020) show that student learning styles affect critical thinking ability.

The limitations of this study include that only students in the classification of visual, auditory, and kinesthetic learning styles were selected as research samples. Students with a combination of two and three learning styles have not been studied because the number of students tends to be small in a population, so it is not balanced with other learning classifications. However, it is possible to research students with a combination of two and three learning styles in the future to obtain more comprehensive results.

\section{Conclusion}

The overall achievement and improvement of students' mathematical critical thinking ability obtained Problem-based learning and viewed from a kinesthetic learning style were better than conventional learning. Meanwhile, in terms of visual and auditory learning styles, the achievement and improvement of mathematical critical thinking ability of students who obtained Problem-based learning descriptively were better than conventional learning. However, in statistical testing, it was not significantly different. Based on this, problem-based learning is considered effective for developing mathematical critical thinking ability, especially for kinesthetic learning styles. In the research carried out, the researcher did not specifically discuss the critical thinking ability of students with combined learning styles so that this study can be followed up in the subsequent research.

\section{Conflicts of Interest}

The author declare no conflict of interest regarding the publication of this manuscript. In addition, the ethical issues, including plagiarism, misconduct, data fabrication and/or falsification, double publication and/or submission, and redundancies have been completely by the author.

\section{References}

Ali, S. S. (2019). Problem based learning: A student-centered approach. English Language Teaching, 12(5), 73-78. https://doi.org/10.5539/elt.v12n5p73

Alrahlah, A. (2016). How effective the problem-based learning (PBL) in dental education. A critical review. The Saudi Dental Journal, 28, 155-161. https://doi.org/10.1016/j.sdentj.2016.08.003.

Asyari, M., Al Muhdhar, M. H. I., Susilo, H., \& Ibrohim. (2016). Improving critical thinking skills through the integration of problem-based learning and group investigation. International Journal for Lesson and Learning Studies, 5(1), 36-44. https://doi.org/10.1108/IJLLS-10-2014-0042.

Aziz, A., Ahyan, S., \& Fauzi, L. M. (2016). Implementasi model problem based learning (PBL) dalam meningkatkan kemampuan berpikir kritis mahasiswa melalui Lesson Study [Implementation of the problem based learning (PBL) model in improving students' 
critical thinking skills through Lesson Study]. Jurnal Elemen, 2(1), 83-91. https://doi.org/10.29408/jel.v2i1.179.

Barrett, T., MacLabhrainn, I., \& Fallon, H. (2005). Handbook of enquiry and problem-based learning: Understanding problem-based learning. Centre for Excellence in Learning and Teaching, NUI Galway.

Cohen, L., Manion, L., \& Morrison, K. (2007). Research methods in education, sixth edition. Routledge. https://doi.org/10.4324/9780203029053

Darhim, Prabawanto, S., \& Susilo, B.E. (2020). The effect of problem-based learning and mathematical problem posing in improving student's critical thinking skills. International Journal of Instruction, 13(4), 103-116. https://doi.org/10.29333/iji.2020.1347a

DePorter, B., \& Hernacki, M. (2010). Quantum learning: Membiasakan belajar nyaman dan menyenangkan [Quantum learning: Make learning comfortable and fun]. Kaifa.

Dwyer, C. P., Hogan, M. J., \& Stewart, I. (2014). An integrated critical thinking framework for the $21 \mathrm{st}$ century. Thinking Skills and Creativity, 12, 43-52. https://doi.org/10.1016/j.tsc.2013.12.004.

Fajari, L.E.W, Sarwanto, S., \& Chumdari, C. (2020). The effect of problem-based learning multimedia and picture media on students' critical-thinking skills viewed from learning motivation and learning styles in elementary school. Ilkogretim Online, 19(3), 17971811. https://doi.org/10.17051/ilkonline.2020.735165

Fajrianthi, F., Hendriani, W., \& Septarini, B. G. (2016). Pengembangan tes berpikir kritis dengan pendekatan item response theory [Development of critical thinking test with item response theory approach]. Jurnal Penelitian dan Evaluasi Pendidikan, 20(1), 45-55. https://doi.org/10.21831/pep.v20i1.6304

FitzPatrick, B., \& Schulz, H. (2015). Do curriculum outcomes and assessment activities in science encourage higher order thinking? Canadian Journal of Science, Mathematics and Technology Education, $15(2)$ $136-154$. https://doi.org/10.1080/14926156.2015.1014074.

Gholami, M., Moghadam, P. K., Mohammadipoor, F., Tarahi, M. J., Sak, M., Toulabi, T., \& Pour, A. H. H. (2016). Comparing the effects of problem-based learning and the traditional lecture method on critical thinking skills and metacognitive awareness in nursing students in a critical care nursing course. Nurse Education Today, 45, 16-21. https://doi.org/10.1016/j.nedt.2016.06.007.

Gleason, N. W. (2018). Higher education in the era of the fourth industrial revolution (p. 229). Springer Nature. https://doi.org/10.1007/978-981-13-0194-0_1

Gorghiu, G., Drăghicescu, L. M., Cristea, S., Petrescu, A.-M., \& Gorghiu, L. M. (2015). Problem-based learning - an efficient learning strategy in the science lessons context. Procedia - Social and Behavioral Sciences, 191, 1865-1870. https://doi.org/10.1016/j.sbspro.2015.04.570.

Hake, R. R. (1998). Interactive-engagement versus traditional methods: A six-thousand-student survey of mechanics test data for introductory physics courses. American journal of Physics, 66(1), 64-74. https://doi.org/10.1119/1.18809

Hananto, R. B., \& Kusmayadi, T. A. (2018, May). Analysis of the critical thinking process of junior high school students in solving geometric problems by utilizing the vak learning styles model. Journal of Physics: Conference Series, 1013(1), Article 012132. https://doi.org/10.1088/1742-6596/1013/1/012132

Hussain, H., \& Anwar, N. (2017). Effects of problem based learning on students' critical thinking skills, attitudes towards learning and achievement. Journal of Educational Research, 20(2), 28-41. $\quad$ http://jer.iub.edu.pk/journals/JER-Vol-20.No2/3_Effects_of_Problem_Based_Learning on_Students\%E2\%80\%99_Critical_Thinkin g_Skills,_Attitudes_towards_Learning_and_Achievement.pdf 
Husnidar, Ikhsan, M. dan Rizal, S. (2014). Penerapan model pembelajaran berbasis masalah untuk meningkatkan kemampuan berpikir kritis dan disposisi matematis siswa [Application of problem-based learning model to improve students' critical thinking ability and mathematical disposition]. Jurnal Didaktik Matematika, 1(1), 71-82.

Karim, A. (2015). Pengaruh gaya belajar dan sikap siswa pada pelajaran matematika terhadap kemampuan berpikir kritis matematika [The effect of learning styles and student attitudes in mathematics lessons on mathematical critical thinking skills]. Formatif: Jurnal Ilmiah Pendidikan MIPA, 4(3), 188-195. https://doi.org/10.30998/formatif.v4i3.154

Laksana, D. N. L. (2019). Kesulitan belajar anak dengan gaya belajar yang berbeda dalam menghadapi pembelajaran 4.0 serta strategi yang digunakan [Learning difficulties of children with different learning styles in dealing with learning 4.0 and the strategies used]. Pembelajaran di era big data dalam berbagai kondisi belajar (hal. 1-16). CV. AA. Rizky.

Masek, A., \& Yamin, S. (2011). The effect of problem-based learning on critical thinking ability: a theoretical and empirical review. International Review of Social Sciences and Humanities, 2(1), 215-221.

Mulyanto, H., Gunarhadi, G., \& Indriayu, M. (2018). The effect of problem based learning model on student mathematics learning outcomes viewed from critical thinking skills. International Journal of Educational Research Review,3(2), 37-45. https://doi.org/10.24331/ijere.408454

Nadeak, B., \& Naibaho, L. (2020). The effectiveness of problem-based learning on students'critical thinking. Jurnal Dinamika Pendidikan, 13(1), 1-7.

Nursyahidah, F., \& Albab, I. U. (2018). Identifikasi kemampuan berpikir kritis matematis mahasiswa berkemampuan pemecahan masalah level rendah dalam pembelajaran kalkulus integral [Identification of mathematical critical thinking ability of students with low level problem solving ability in integral calculus learning]. Jurnal Elemen, 4(1), 34-49. https://doi.org/10.29408/jel.v4i1.513

Paul, R., \& Elder, L. (2013). Critical thinking: Tools for taking charge of your professional and personal life. Pearson Education.

Perkins, C., \& Murphy, E. (2006). Identifying and measuring individual engagement in critical thinking in online discussions: An exploratory case study. Educational Technology \& Society, 9, 298-307. https://www.jstor.org/stable/jeductechsoci.9.1.298

Rosmaiyadi, R. (2017). Analisis kemampuan berpikir kritis matematis siswa dalam learning cycle 7e berdasarkan gaya belajar [Analysis of students' mathematical critical thinking ability in learning cycle 7e based on learning style]. AKSIOMA: Jurnal Program Studi Pendidikan Matematika, 6(1), 12-19. https://doi.org/10.24127/ajpm.v6i1.722

Samejima, M., Hisakane, D., \& Komoda, N. (2015). Automatic annotation method on learners' opinions in case method discussion. Interactive Technology and Smart Education, 12(2), 90-99. https://doi.org/10.1108/ITSE-04-2015-0003

Saputra, M. D., Joyoatmojo, S., Wardani, D. K., \& Sangka, K. B. (2019). Developing criticalthinking skills through the collaboration of jigsaw model with problem-based learning model. International Journal of Instruction, 12(1), 1077-1094. https://doi.org/10.29333/iji.2019.12169a

Schoenberger-Orgad, M., \& Spiller, D. (2014). Critical thinkers and capable practitioners. Journal of Communication Management, 18(3), 210-221. https://doi.org/10.1108/JCOM-11-2012-0085.

Şendağ, S., \& Ferhan Odabaşi, H. (2009). Effects of an online problem-based learning course on content knowledge acquisition and critical thinking skills. Computers and Education, 53, 132-141. https://doi.org/10.1016/j.compedu.2009.01.008. 
Sianturi, A., Sipayung, T. N., \& Simorangkir, F. M. A. (2018). Pengaruh model problem based learning (PBL) terhadap kemampuan berpikir kritis matematis siswa SMPN 5 Sumbul [The effect of the problem based learning (PBL) model on the students' mathematical critical thinking skills of SMPN 5 Sumbul]. Union: Jurnal Pendidikan Matematika, 6(1), 29-42. https://doi.org/10.30738/.v6i1.2082

Susilo, B. E. (2011). Analisis kesulitan belajar mahasiswa pada materi limit fungsi mata kuliah kalkulus dalam perspektif gaya belajar dan gaya berpikir mahasiswa [Analysis of student learning difficulties on the limit function of the calculus course in the perspective of student learning styles and thinking styles]. [Unpublished Master Thesis] Postgraduate Program of Universitas Sebelas Maret.

Susilo, B. E., Darhim, D., \& Prabawanto, S. (2018). Supporting activities for critical thinking skills development based on students' perspective. In Proceedings of the 1st International Conference on Science and Technology for an Internet of Things. European Alliance for Innovation (EAI). https://doi.org/10.4108/eai.19-10-2018.2281320

Susilo, B. E., Darhim, D., \& Prabawanto, S. (2019). Students critical thinking skills toward concepts differences in finding area of a plane region and definite integral. Unnes Journal of Mathematics Education, 8(1), 1-7.

Trilling, B., \& Fadel, C. (2009). 21st century skills learning for life in our times. Jossey-Bass.

Vong, S. A., \& Kaewurai, W. (2017). Instructional model development to enhance critical thinking and critical thinking teaching ability of trainee students at regional teaching training center in Takeo Province, Cambodia. Kasetsart Journal of Social Sciences, 38, 88-95. https://doi.org/10.1016/j.kjss.2016.05.002.

Widiawati, L., Joyoatmojo, S., \& Sudiyanto. (2018). Higher order thinking skills as effect of problem-based learning in the 21 st century learning. International Journal of Multicultural and Multireligious Understanding, 5(3), 96-105. https://ijmmu.com/index.php/ijmmu/article/view/223/139.

Zamzam, K. F. (2016). Pendekatan problem-based learning untuk mengembangkan kemampuan berpikir kritis mahasiswa [Problem-based learning approach to develop students' critical thinking ability]. Pedagogia: Jurnal Pendidikan, 5(2), 279-286. https://doi.org/10.21070/pedagogia.v5i2.261

Zetriuslita, Ariawan, R., \& Nufus, H. (2016). Analisis kemampuan berpikir kritis matematis mahasiswa dalam menyelesaikan soal uraian kalkulus integral berdasarkan level kemampuan mahasiswa [Analysis of students' mathematical critical thinking skills in solving integral calculus description problems based on students' ability levels]. Infinity Journal, 5(1), 56-65. https://doi.org/10.22460/infinity.v5i1.p56-66 